\title{
Analisa Pengaruh Economic Value Added, Return on Asset dan Return on Ekuitas Terhadap Market Value Added Perusahaan Saham Teraktif Di Bursa Efek Indonesia
}

\author{
Andi Martias \\ Universitas Bina Sarana Informatika \\ Email: andi.aim@bsi.ac.id
}

\begin{tabular}{ccc}
\hline Diterima & Direvisi & Disetujui \\
$06-07-2020$ & $06-09-2020$ & $28-09-2020$ \\
\hline
\end{tabular}

\begin{abstract}
Abstrak - Tujuan dari penelitian ini adalah untuk menguji secara empiris hubungan antara economic value added (EVA), return on asset (ROA), dan return on ekuitas (ROE) dengan market value added (MVA) di Bursa Efek Indonesia (BEI) untuk Perusahaan yang berkembang dengan Saham Teraktif pada periode penelitian periode 2015-2019. Jumlah sampel penelitian setelah diseleksi dengan teknik purposive sampling adalah sebanyak 7 perusahaan dimana merupakan saham teraktif. Analisis data yang digunakan adalah analisis regresi linier berganda menggunakan MINITAB. Hasil penelitian ini menunjukkan bahwa nilai koefisien determinasi (Adjusted $R$ Square) yang menunjukan variabel independen mempengaruhi variabel dependen dan sisanya dipengaruhi oleh variabel lain diluar penelitian ini. Hasil Uji F menunjukkan bahwa variabel independen Economic Value Added (EVA) dan return on asset (ROA) secara simultan tidak berpengaruh signifikan terhadap Market Value Added (MVA) namun return on ekuitas (ROE) memiliki pengaruh hubungan yang signifikan dengan MVA dalam jangka panjang. Bagi calon investor yang hendak tidak hanya menanamkan dananya pada saham perusahaan dengan melihat faktor Market Value Added (MVA) karena berdasarkan hasil dari penelitian ini menunjukkan bahwa variabel Market Value Added (MVA) tidak berpengaruh signifikan terhadap pergerakan EVA, ROA dan ROE yang diterima oleh pemegang saham perusahaan dengan saham teraktif yang terdaftar di Bursa Efek Indonesia periode 2015-2019.
\end{abstract}

Kata kunci: Market Value Added, Economic Value Added, Return on Asset, Return on Ekuitas, Saham Teraktif

\begin{abstract}
The purpose of this study is to empirically examine the relationship between economic value added $(E V A)$, return on assets (ROA), and return on equity (ROE) with market value added (MVA) on the Indonesia Stock Exchange (BEI) for companies. which developed with the most active stocks in the study period 2015-2019. The number of research samples after being selected by purposive sampling technique were 7 companies which were the most active stocks. The data analysis used is multiple linear regression analysis using MINITAB. The results of this study indicate that the value of the coefficient of determination (Adjusted $R$ Square) which shows the independent variable affects the dependent variable and the rest is influenced by other variables outside of this study. The F test results show that the independent variables Economic Value Added (EVA) and return on assets (ROA) simultaneously do not have a significant effect on Market Value Added (MVA) but return on equity (ROE) has a significant relationship with MVA $\neg$ in the long run. . For potential investors who want not only to invest their funds in company shares by looking at the Market Value Added (MVA) factor because the results of this study indicate that the Market Value Added (MVA) variable does not have a significant effect on the movement of EVA, $R O A$ and ROE received by the holder. shares of companies with the most active shares listed on the Indonesia Stock Exchange for the period 2015-2019.
\end{abstract}

Keywords: Market Value Added, Economic Value Added, Return on Assets, Return on Equity, Most Active Stock

\section{PENDAHULUAN}

Perusahaan yang berkembang menempati posisi dominan dalam pembangunan suatu negara. Perusahaan yang berkembang melayani kebutuhan petani, industrialis, pedagang, dan semua bagian masyarakat lainnya. Ini memfasilitasi untuk mempercepat pertumbuhan ekonomi suatu negara dan mengarahkan roda ekonomi menuju tujuannya kemandirian di semua bidang. Perusahaan yang berkembang saat ini adalah menghadapi persaingan yang tajam, perubahan investasi dan inovasi. Jadi manajemen yang efektif membantu memberikan yang lebih baik layanan dan memperluas kegiatan mereka. Manajer membuat perencanaan strategis untuk kinerja Perusahaan yang berkembang . Karena itu mereka butuh kreativitas, inovasi dan intuisi.

Sektor perusahaan yang berkembang dianggap sebagai sumber pembiayaan yang penting bagi kebanyakan proses perekonomian suatu negara. 
Laporan keuangan yang memberikan informasi yang sesuai akan mengarah pada peningkatan fungsi dan kegiatan. Perusahaan yang berkembang internal mereka sebagai serta lingkungan eksternal menjadi lebih kompleks. Dalam masyarakat yang dinamis ini para manajer harus mampu mengantisipasi perubahan dan dampaknya dan mengambil tindakan yang tepat untuk menghadapi perubahan ini. Kemajuan sifat bisnis dan kinerja manajemen telah mendorong kebutuhan orang untuk membangun pengukuran keuangan yang lebih efektif dan terstruktur. Menurut beberapa artikel tren terbaru dalam pengukuran kinerja perusahaan yang berkembang banyak mendorong kebutuhan orang untuk membangun pengukuran keuangan yang lebih efektif dan terstruktur. Selain itu juga banyak perusahaan yang berkembang mengalami kesulitan dalam menerapkan kerangka kerja pengukuran.

Masalah-masalah dari tahun 1990-an adalah hari ini masih relevan terkait dengan variabel untuk diukur, cara mengakses data, dan sebagainya. Kinerja efektif pengukuran diyakini sangat penting dalam memastikan keberhasilan implementasi suatu organisasi strategi. Hasil pengukuran kinerja akan membantu para manajer untuk menghasilkan pengambilan keputusan yang efektif proses apakah di tingkat operasional atau strategis. Beberapa tahun terakhir telah mengembangkan pendekatan baru untuk penilaian kinerja Perusahaan yang berkembang.

Sejak era tahun 1991 muncul economic value added (EVA) lebih dari 300 Perusahaan yang berkembang mengadopsi disiplin ini di dunia. Konsep EVA adalah pendekatan yang relatif baru untuk menilai kinerja Perusahaan yang berkembang.

Berbeda dengan konvensional ukuran kinerja Perusahaan yang berkembang yang memerlukan analisis komparatif dengan Perusahaan yang berkembang sejenis di industri, sementara EVA dapat berdiri sendiri. Metode EVA yang berhasil dibuat Perusahaan yang berkembang adalah faktor yang paling relevan dalam pembentukan Perusahaan yang berkembang yang pada akhirnya akan mempengaruhi Laporan keuangan yang memberikan informasi yang sesuai . Studi ini mengevaluasi Perusahaan yang berkembang Laporan keuangan yang memberikan informasi yang sesuai berdasarkan economic value added (EVA) yang merupakan konsep modern yang diperkenalkan untuk tujuan mengevaluasi kinerja Perusahaan yang berkembang.

Perkembangan investasi sangat penting untuk inisiatif yang menghubungkan proses bisnis untuk mengejar ketinggalan dengan perusahaan yang berkembang investasi tersebut. Jadi, perbatasan informatika dan investasi dapat berpengaruh pada bisnis kinerja di perusahaan yang berkembang yang dihasilkan keunggulan kompetitif untuk suatu perusahaan yang berkembang . Meskipun ini perusahaan yang berkembang manfaat, kemampuan untuk menghasilkan keunggulan kompetitif di suatu negara berkemang telah dipertanyakan sebagai kemampuan investasi bergeser dari sumber daya unik ke keuangan pasar. Demikian pula, kemajuan di bidang informatika dan investasi di Internet dunia telah membuatnya semakin untuk bisnis untuk membuat keputusan mengenai kinerja bisnis. Memainkan kinerja bisnis peran penting dalam pelaporan keuangan selain memberikan nilai pengguna informasi relevansi seperti pemegang saham dan investor di perusahaan yang berkembang saat ini. Saat ini, penciptaan nilai dan nilai bagi pemegang saham termasuk di dalamnya tujuan paling penting dari perusahaan yang berkembang dan pemilik. Memaksimalkan nilai pemegang saham telah menjadi hal baru paradigma Perusahaan yang berkembang.

Pola standar yang berbeda digunakan untuk akuntansi dan laporan keuangan yang memberikan informasi yang sesuai. Revenue berbasis akuntansi sangat kriteria evaluasi kinerja tradisional yang penting. Namun, revenue berbasis akuntansi dapat dirubah-rubah melalui berbagai metode. Perusahaan yang berkembang perlu lebih dapat diandalkan dan menambah ukuran kinerja dari akuntansi tradisional ukuran kinerja. Dalam beberapa tahun terakhir, tindakan berbasis nilai telah diterima banyak perhatian. Selama dua dekade terakhir, nilai tambah ekonomi berdasarkan economic value added (EVA) diperhatikan oleh beberapa peneliti akuntansi, bisnis dan keuangan, Perusahaan yang berkembang profesional, dan Perusahaan yang berkembang konsultan dan dengan demikian mereka menerima keterbatasan ukuran kinerja tradisional. Dapat dikatakan juga bahwa banyak pakar mengkritik tindakan tradisional karena proses yang tidak sesuai tersebut.Dimana menunjukkan bahwa tindakan tradisional tidak tepat pedoman untuk membuat keputusan strategis sesuai untuk metrik berbasis nilai. Secara tidak langsung kita dapat mengatakan bahwa tindakan tradisional masih memainkan peran penting peran penting sebagai instrumen untuk menilai ekonomi dan kinerja akuntansi perusahaan yang berkembang . Namun, langkah-langkah tradisional hanya memberikan informasi dari penilaian tentang kinerja masa lalu.

Analisa yang dilakukan pada tulisan ini adalah untuk menganalisa pengaruh pada market value added (MVA) di pasar bursa saham yaitu ukuran kinerja eksternal, dibandingkan dengan tiga akuntansi ukuran kinerja seperti economic value added (EVA), return on asset (ROA) dan return on ekuitas (ROE) perusahaan yang berkembang dengan saham yang teraktif terdaftar di BEI selama pra dan pasca global krisis keuangan. economic value added (EVA) adalah ukuran keuangan berbasis nilai, yang berkaitan dengan tolok ukur biaya modal dan menyediakan peta jalan ke target kritis untuk meningkatkan market value added (MVA). Economic value added (EVA) adalah ukuran internal kinerja yang mendorong market value added (MVA). 
(Stewart, 2016) didefinisikan sebagai economic value added (EVA) yang memperhitungkan biaya modal penuh, termasuk biaya ekuitas pemegang. Economic value added (EVA) adalah keuangan ukuran kinerja yang datang lebih dekat daripada tradisional lainnya langkah-langkah dalam menangkap keuntungan ekonomi sebenarnya dari suatu Perusahaan yang berkembang. Demikian pula, economic value added (EVA) adalah metode penting untuk mengukur ekonomi nilai bisnis setelah mempertimbangkan biaya modal termasuk hutang biaya dan biaya ekuitas.

Dengan demikian, economic value added (EVA) mendorong manajer untuk mengoptimalkan penggunaan sumber daya untuk bisnis. economic value added (EVA) menyediakan investasi untuk pilih opsi berisiko rendah untuk mengevaluasi nilai Perusahaan yang berkembang. Economic value added (EVA) adalah ukuran kinerja paling langsung terkait dengan penciptaan kekayaan pemegang saham atas waktu dalam bisnis. Dengan demikian bisa disimpulkan bahwa economic value added (EVA) diakui sebagai alat penting untuk pengukuran kinerja bisnis dan pengelolaan.

Beberapa penelitian yang lain menyimpulkan bahwa masih ada bukti campuran tentang keunggulan economic value added (EVA) dibandingkan pengukuran kinerja tradisional alat. Tidak seperti ukuran tradisional, economic value added (EVA) lebih unggul dari laba akuntansi sebagai ukuran penciptaan nilai karena mengakui biaya modal dimana terdapat hasil untuk meneliti akuntansi umum mengukur variabel dengan economic value added (EVA). Temuannya menyarankan bahwa economic value added (EVA) adalah ukuran yang kuat dan efisien untuk menggambarkan operasi Perusahaan yang berkembang . Itu lebih kuat dari pada umumnya dan tradisional langkah-langkah untuk menggambarkan nilai saham Perusahaan yang berkembang. Secara tidak langsung dapat disimpulkan bahwa economic value added (EVA) adalah statistic pengukuran yang paling penting untuk pengukuran nilai operasi Perusahaan yang berkembang untuk mengevaluasi aset perusahaan yang berkembang . Market value added (MVA) adalah ukuran kinerja eksternal, yang dianggap sebagai indikator terbaik dari penciptaan nilai pemegang saham. Itu market value added (MVA) positif menunjukkan bahwa nilai dan investasi dibuat oleh manajemen lebih dari modal yang disediakan oleh investor, sebaliknya. Penelitian ini menganalisis apakah dampak profitabilitas memiliki tautan BIST terdaftar Perusahaan yang berkembang market value added (MVA). Studi ini juga menguji dan mengkorelasikan return on asset (ROA) dan Variabel return on ekuitas (ROE) dengan market value added (MVA) sebagai nilai kinerja berbasis pasar sehingga untuk menguji apakah economic value added (EVA) telah memberikan lebih dari akuntansi tradisional metrik kinerja. Motivasi penelitian kami adalah untuk menguji dampak metrik market value added (MVA) pada ukuran kinerja bisnis sebagai indikator profitabilitas. Salah satu contoh motivasi ini adalah pada era 1980 di mana mereka menguji hipotesis bahwa operasi Perusahaan yang berkembang dapat memengaruhi kinerjanya tergantung pada nilai pasar. Hasil empiris mereka menunjukkan bahwa pertumbuhan investasi berhubungan positif dengan nilai lebih di pasar modal. Untuk melakukannya, ukuran kinerja kejadian profitabilitas pada Perusahaan yang berkembang Perusahaan yang berkembang yang terdaftar di Turki seperti metrik tradisional dan berbasis nilai. Kami menyimpulkan bahwa ada korelasi antara economic value added (EVA) dan kinerja bisnis yang diukur oleh market value added (MVA). Analisa pada tulisan ini dimulai dengan memeriksa kembali masalah yang berkaitan dengan bisnis kinerja. Nilai ini Studi menentukan analisis empiris hubungan ini di konteks ekonomi dan nilai tambah berikut relevansi untuk pengukuran market value added (MVA).

\section{TINJAUAN PUSTAKA}

Relevansi nilai akuntansi tradisional dan nilai ukuran kinerja berbasis telah lama diperdebatkan dalam baru-baru ini tahun. (Stewart, 2016), misalnya, menyelidiki hubungan tersebut antara economic value added (EVA) dan market value added (MVA) Perusahaan yang berkembang AS dan dia menemukan positif dan hubungan yang kuat antara EVA dan market value added (MVA). Demikian pula, (Lehn and Anil K. Makhija, 2016) menemukan bahwa baik economic value added (EVA) dan market value added (MVA) berkorelasi positif dengan pengembalian saham (Maditinos, D.I., Seviç, Z., Theriou, 2017). (Kramer, J.K., Pushner, 2017) menyiratkan bahwa market value added (MVA) dan NOPAT adalah hasil positif tetapi economic value added (EVA) selama periode tersebut adalah hasil negatif rata-rata. (Ferguson, R., Rentzler, J., Yu, 2015) menemukan bahwa economic value added (EVA) dan market value added (MVA) miliki hubungan yang paling nyaman dibandingkan dan sesuai ketersediaan data yang dipilih (Prasad, H., Shrimal, 2015).

Studi sebelumnya menunjukkan bahwa dampak profitabilitas pada market value added (MVA) masih bukti campuran tentang kinerja berbasis akuntansi mengukur dan mengukur berdasarkan nilai dalam literatur. (Ferguson, R., Rentzler, J., Yu, 2015), misalnya, meneliti apakah EVA lebih tinggi tautannya dengan pengembalian saham dari ukuran kinerja akuntansi. Mereka memberikan hasil yang beragam dan kontroversial dalam sampel mereka. (Reddy, N.R. V.R., Reddy, 2015) menunjukkan bahwa economic value added (EVA) ' adalah metrik terbaik yang paling sesuai untuk mengukur nilai pemegang saham. (Bernier, G., Mouelhi, 2015) dan (Martias, 2017) menyelidiki hubungan antara market value added (MVA) dan economic value added (EVA), return on asset (ROA) 
dan return on ekuitas (ROE) pada perusahaan yang berkembang asuransi terdaftar di Bursa Efek Indonesia (BEI). Mereka menemukan hubungan antara economic value added (EVA) dan kinerja berbasis nilai lainnya tindakan dengan market value added (MVA). Terdapat penelitian menyelidiki hubungan antara economic value added (EVA) dan return on asset (ROA) di Bursa Efek Indonesia dan menemukan bahwa tidak ada hubungan antara economic value added (EVA) dan return on asset (ROA) di Bursa Efek Indonesia (BEI).

(Khan, S., Chouhan, V., Chandra, B., Goswami, 2016) meneliti apakah economic value added (EVA) dari Perusahaan yang berkembang yang terdaftar Perusahaan yang berkembang di pasar efek BSE menciptakan nilai bagi pemegang saham. (Nakhaei, H., Hamid, 2016) mengamati bahwa ada yang signifikan hubungan antara economic value added (EVA), dan return on ekuitas (ROE) dengan market value added (MVA), tetapi ada tidak ada hubungan yang signifikan antara return on asset (ROA) dan MVA. Juga, (Bernier, G., Mouelhi, 2015) menemukan bahwa economic value added (EVA) bukanlah tindakan yang sangat baik dalam hal itu tautan dengan market value added (MVA). (Prasad, H., Shrimal, 2015) meneliti hubungan antara langkahlangkah akuntansi yang dipilih dan market value added (MVA) infrastruktur Perusahaan yang berkembang di India. Mereka menemukan bahwa ada hubungan yang signifikan antara ROCE, return on ekuitas (ROE) dan EPS dengan market value added (MVA). (Fathabadi, L., Fathi, D., Damiri, 2016) meneliti pentingnya economic value added (EVA) di antara tradisional lainnya langkah-langkah akuntansi dalam menentukan pengembalian saham. Mereka tersirat bahwa ada hubungan positif dan langsung antara EVA dan market value added (MVA) selama periode yang dipilih. (Sharma \& Kumar, 2010) berfokus pada apakah economic value added (EVA) akan mendorong market value added (MVA) atau tidak di pilih Perusahaan yang berkembang sektor publik India selama periode 2010-2014. Mereka Temuan menunjukkan bahwa economic value added (EVA) memiliki dampak pada market value added (MVA).

\section{Pengembangan Hipotesis}

Perkembangan dunia investasi paling baik didefinisikan tidak hanya sebagai tradisional investasi modal tetapi juga sebagai investasi tujuan universal. Lebih penting lagi, menggunakan investasi di perusahaan yang berkembang menguntungkan secara ekonomi sebagian besar karena mereka menyediakan inovasi pelengkap (Brynjolfsson, E., Hitt, 2017). Oleh karena itu, Perusahaan yang berkembang seperti ukuran kinerja berbasis nilai adalah pendorong nilai penting dalam perekonomian. Menemukan ukuran yang unggul untuk mengevaluasi kinerja berbasis nilai bisnis adalah salah satunya masalah penting dari penelitian akuntansi dan keuangan terbaru sebagai sebagian besar diversifikasi bisnis seperti industri perusahaan yang berkembang dan informatika dan Perusahaan yang berkembang investasi adalah perbedaan antara nilai pasar Perusahaan yang berkembang dan modal dipasok oleh investor selama periode waktu tertentu. Karena itu, market value added (MVA) terkait dengan economic value added (EVA) karena nilai sekarang dari nilai economic value added (EVA) di masa depan. Apalagi economic value added (EVA) adalah tolok ukur kinerja bisnis yang diberikan tahun fiskal, sedangkan market value added (MVA) adalah angka yang dihasilkan pasar yang kita menghitung dengan mengurangi modal yang diinvestasikan dalam suatu perusahaan yang berkembang dari jumlah dari total nilai pasar dari ekuitas Perusahaan yang berkembang dan nilai buku utangnya.

Penelitian ini juga meneliti krisis ekonomi menjadi gangguan eksogen, dan upaya untuk membangun hubungan mendasar antara kinerja dari Perusahaan yang berkembang informatika dan investasi, moderat efek dari krisis dan market value added (MVA). Alipour dan Pejman (2015) menyimpulkan bahwa laba atas penjualan (ROS) dan return on asset (ROA) lebih kuat daripada economic value added (EVA) dalam menjelaskan pasar Perusahaan yang berkembang nilai untuk periode 2003-2008. Kramer dan Peters (2011) berpendapat bahwa biaya marjinal menggunakan economic value added (EVA) sebagai proxy untuk market value added (MVA) tidak dibenarkan oleh keuntungan marjinal. Misra dan Kanwal (20017) Temuan bahwa langkah-langkah akuntansi tradisional tidak dapat memprediksi kinerja bisnis dan bahwa EVA secara signifikan terkait dengan market value added (MVA).

Dengan demikian, market value added (MVA) adalah proksi yang sangat berguna dalam mengevaluasi pemegang saham nilai, mengingat biaya peluang modal serta Turki kinerja Perusahaan yang berkembang informatika dan investasi. Adapun hipotesis yang dianggap relevan untuk dianalisa adalah

H0: Tidak ada pengaruh hubungan signifikan Antara economic value added (EVA), return on asset (ROA), return on ekuitas (ROE) dan market value added (MVA)

H1: Ada hubungan yang signifikan antara economic value added (EVA) dan market value added (MVA). $\mathrm{H} 2$ : Ada hubungan yang signifikan antara return on asset (ROA) dan market value added (MVA).

H3: Ada hubungan yang signifikan antara return on ekuitas (ROE) dan market value added (MVA).

\section{METODE PENELITIAN}

\section{Pemilihan Sampel}

Perusahaan yang berkembang dapat dianggap sebagai faktor penting mendorong pertumbuhan ekonomi dalam masyarakat industri. 
Berinvestasi dalam hal ini daerah umumnya dianggap memiliki potensi besar untuk dikurangi biaya, meningkatkan produktivitas, dan meningkatkan standar hidup untuk konteks individu dan bisnis. Lebih penting, Perusahaan yang berkembang informatika dan investasi telah menghadapi modifikasi yang lebih besar untuk perubahan investasi, serta harus menanggapi dengan cepat perubahan dalam kebutuhan pemegang saham seperti pelanggan, karyawan, komunitas dan pengguna informasi lainnya. Dalam sangat tidak pasti variasi eksternal, penggunaan ukuran kinerja akuntansi mungkin tidak memadai untuk evaluasi dan perencanaan kinerja masa depan bisnis. Dengan demikian, kami fokus pada kinerja berbasis nilai langkah-langkah untuk perusahaan yang berkembang. Sampel kami terdiri dari semua Perusahaan yang berkembang dengan saham teraktif yang terdaftar di Bursa Efek Indonesia (BEI) pada periode pengamatan 2015-2019. Kumpulan data dibuat dari laporan keuangan Perusahaan yang berkembang pada saham teraktif tersebut . Sampel terdiri dari observasi Perusahaan yang berkembang untuk data laporan keuangan yang memiliki semua data untuk periode 5 tahun. Dengan demikian, untuk dimasukkan dalam sampel, Perusahaan yang berkembang harus memenuhi kriteria: memiliki data keuangan lengkap dilaporkan dalam aliran data untuk tahun 2015 dan 2019.

Tabel 1. Kolektif Data

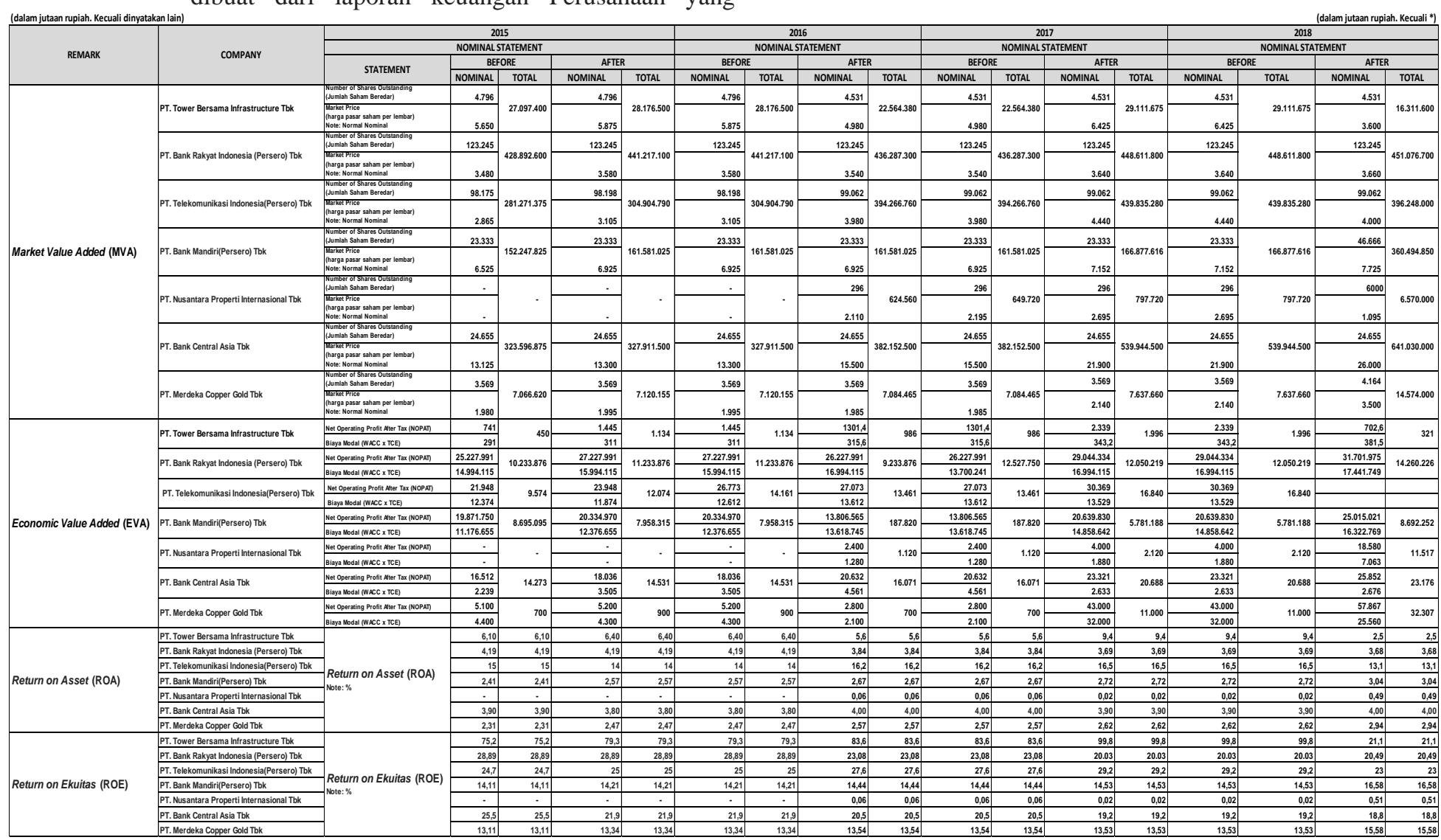

Sumber : Bursa Efek Indonesia 


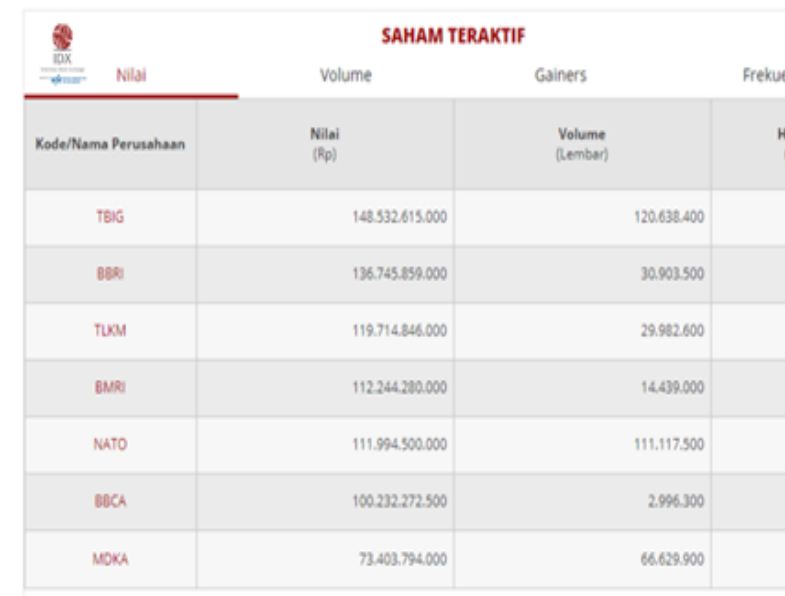

Sumber:https://www.idx.co.id/data-pasar/ringkasanperdagangan

\section{Ukuran Kinerja Bisnis}

Kami menggunakan market value added (MVA) sebagai ukuran kinerja bisnis berbasis pasar. Untuk tes tambahan, kami menggunakan return on asset (ROA), return on ekuitas (ROE) dan economic value added (EVA) sebagai ukuran akuntansi berbasis kinerja Perusahaan yang berkembang. Dalam penelitian yang dialukakan ini, kami menggunakan pengukuran kinerja berbasis nilai market value added (MVA) sebagai eksternal ukuran kinerja, sementara kami menggunakan ukuran kinerja internal seperti economic value added (EVA), return on asset (ROA) dan return on ekuitas (ROE). Dalam penelitian ini, model penelitian menganggap kami menggunakan economic value added (EVA), return on asset (ROA), dan return on ekuitas (ROE) sebagai variabel independen. Studi sebelumnya telah banyak menggunakan market value added (MVA) sebagai proxy untuk pasar kinerja bisnis berbasis. Telah terbukti kuat untuk berbeda periode waktu dan negara sampel yang dipilih. Market value added (MVA) dihitung sebagai perbedaan antara pasar Perusahaan yang berkembang nilai dan total modal yang diinvestasikan dalam bisnis (Liao, Hemmerlin, Bach, \& Chye, 2016).

Proxy pertama variabel :

MVA = Nilai Pasar Saham - Nilai Buku

Economic Value Added (EVA), yang merupakan variabel independen proksi pertama, mengukur sisa pendapatan sebagai penghitungan selisih antara biaya Perusahaan yang berkembang modal dan pengembalian modal, yang dinyatakan sebagai positif atau hasil negatif (Young, S.D.,O’Byrne, 2017).

EVA $=$ NOPAT $-($ TCE $\times$ WACC $)$
Note:

NOPAT $=$ Net Operating Profit After Tax.

TCE $=$ Total Capital Employed .

WACC $=$ Weight Average Cost of Capital.

Proxy kedua sebagai variabel independen:

\section{Return on Asset (ROA)}

Proxy ketiga sebagai variabel independen:

Return on Ekuitas (ROE)

\subsection{Empirical Model}

MVAit $=\beta 0+\beta 1 E V A i t+\beta 2$ ROEit $+\beta 3$ ROAit + uit.

Note:

uit adalah random disturbance term

\section{HASIL DAN PEMBAHASAN}

\section{Statistik Deskriptif}

Interpretasi dari temuan empiris juga disajikan di bagian ini. Statistik penelitian deskriptif diberikan pada Tabel 1. Tabel 1 menyediakan statistik dari variabel yang dikumpulkan. Nilai-nilai minimum, maksimum, rata-rata, standar deviasi dependen variabel (MVA) dan variabel independen (EVA, ROA, dan ROE) dari sampel 7 perusahaan yang berkembang dihitung dari 2015 hingga 2019. Tabel melaporkan statistik deskriptif untuk semua variabel yang digunakan dalam analisis utama makalah untuk sampel 7 perusahaan yang berkembang dengan saham teraktif. MVA adalah Kapitalisasi Pasar dikurangi Total Biasa Ekuitas Pemegang Saham, dan EVA adalah perbedaan antara Perusahaan yang berkembang saham teraktif biaya modal dan pengembalian modal. ROE (ROA) bersifat informatif dan laba bersih kumulatif Perusahaan yang berkembang investasi selama tahun 2015 dan 2019, dibagi dengan nilai buku ekuitas (total aset).

Tabel 2. Summary of Descriptive Statistics

\begin{tabular}{cccccc}
\hline VARIABEL & N & $\begin{array}{c}\text { MEAN } \\
\pm\end{array}$ & SD & MINIMUM & MAXIMUM \\
\hline MVA & 557 & 1.4739 & 6.4592 & -1.4612 & 5.6671 \\
EVA & 557 & -0.7823 & 3.9843 & -3.8321 & 4.3325 \\
ROA & 557 & 0.1436 & 0.0731 & -0.5391 & 0.6734 \\
ROE & 557 & 0.2148 & 0.2173 & -0.7391 & 0.8923
\end{tabular}

SD: Standard Deviation

Menurut Tabel 2, MVA, ukuran penilaian pasar kami, memiliki nilai rata-rata 1.4749 dan berkisar antara -1.4612 hingga 5.6671. EVA, ukuran penilaian pasar kami, memiliki nilai rata-rata -0.7823 
dan berkisar dari -3.8321 hingga 4.3325. Profitabilitas Perusahaan yang berkembang, yang diukur dengan ROA, bervariasi antara -0.5391 dan 0.6734, dengan rata-rata 0.1436 . Selain itu, profitabilitas Perusahaan yang berkembang , sebagaimana diukur oleh ROE, bervariasi antara .7391 dan 0.8923 , dengan rata-rata 0.2148. Lebih penting lagi, statistik deskriptif menunjukkan EVA itu memiliki hubungan negatif dan signifikan dengan MVA.

Tabel 3. Summary Result Analisa Regresi Linier Berganda

\begin{tabular}{lcccc}
\multicolumn{1}{c}{ Model } & \multicolumn{2}{c}{$\begin{array}{c}\text { Unstandardized } \\
\text { Coefficients } \\
\text { Std. }\end{array}$} & $\begin{array}{c}\text { Standardized } \\
\text { Coefficients }\end{array}$ & \\
\hline & B & Error & Beta & \multicolumn{1}{c}{$\mathrm{t}$} \\
\hline 1 (Constant) & -3.213 & .852 & & -3.112 \\
LN_EVA & -0.56 & .035 & -.203 & -1.677 \\
LN_ROA & -0.37 & .028 & -.187 & -1.296 \\
LN_ROE & -0.91 & .051 & -.093 & -1.119
\end{tabular}

Sumber: Olahan Data 2020

Tabel 4. Summary Result Koefisien Determinasi $\left(\mathrm{R}^{2}\right)$

\begin{tabular}{crrrr} 
Model & $\mathrm{R}$ & \multicolumn{1}{c}{$\begin{array}{c}\mathrm{R} \\
\text { Square }\end{array}$} & $\begin{array}{c}\text { Adjusted R } \\
\text { Square }\end{array}$ & $\begin{array}{l}\text { Std. Error of } \\
\text { the Estimate }\end{array}$ \\
\hline 1 & $.493^{\mathrm{a}}$ & .217 & .084 & .51172177
\end{tabular}

Note: Olahan Data 2020

Tabel 5. Summary Result Uji F

\begin{tabular}{lcrrrr}
\multicolumn{1}{c}{ Model } & $\begin{array}{c}\text { Sum of } \\
\text { Squares }\end{array}$ & Df & $\begin{array}{c}\text { Mean } \\
\text { Square }\end{array}$ & F & Sig. \\
\hline Regression & 0.795 & 4 & 1.627 & 8.771 & .003 a \\
Residual & 8.731 & 557 & .097 & & \\
Total & 11.338 & 1.114 & & & \\
\multicolumn{2}{c}{ Simber: Olahan Data 2020 } & & &
\end{tabular}

Data diatas menyimpulkan variabel EVA, ROA dan ROE berpengaruh signifikan terhadap MVA (Y). Hal ini ditunjukkan dengan uji simultan (uji F) menghasilkan nilai signifikansi sebesar 0,003. Hasil penelitian ini mendukung hasil penelitian dari (Ewer et al., 2016) yang menemukan adanya pengaruh.

Data uji koefisien determinasi menunjukkan hasil angka adanya pengaruh dikedua variable.

Pengaruh Economic Value Added/EVA (X1) terhadap Market Value Added (MVA) (Y).
Penelitian menunjukan adanya pengaruh negatif untuk EVA dengan MVA dengan hasil nilai thitung $1,677<$ tabel dengan tingkat signifikansi $0,126>\alpha=0,05$.

\section{Pengaruh Return on Asset (ROA) (X2) terhadap Market Value Added (MVA) (Y).}

Penelitian menunjukan ROA tidak pengaruh signifikan terhadap MVA. Terbukti dari thitung 1,296 $<$ ttabel dengan tingkat signifikansi $0,196>\alpha=0,05$.

\section{Pengaruh Return on Ekuitas (ROE) (X3) terhadap Market Value Added (MVA) (Y).}

Hasil penelitian ini menyatakan bahwa secara parsial Return on Ekuitas (ROE) berpengaruh signifikan terhadap Market Value Added (MVA). Sig. Terbukti dari thitung $1,119<$ ttabel dengan tingkat signifikansi $0,018<\alpha=0,05$. Sebagai akibatnya, .001 kepercayaan investor terhadap perusahaan semakin .126 meningkat sehingga akan mampu meningkatkan .109 permintaan terhadap saham perusahaan. .018

\section{KESIMPULAN}

Penelitian ini menguji kandungan informasi keuangan MVA dan tiga ukuran kinerja akuntansi tradisional. Lebih jauh, ini Studi juga menguji profitabilitas dan pengaruhnya terhadap nilai pasar ditambahkan dari Perusahaan yang saham teraktif yang terdaftar di Bursa Efek Indonesia, meliputi periode 5 tahun (2015-2019). Berdasarkan pada temuan makalah ini EVA memiliki negatif dan signifikan tidak ada pengaruh interaksi dengan MVA begitupun ROA, sedangkan ROE memiliki signifikan nilai tambah hubungan pasar dalam bentuk pertamabahan laba investasi.

Hasil studi empiris temuan yang ada signifikan hubungan antara EVA dan MVA, bukti yang tidak mendukung studi sebelumnya (Sharma, A.K., Kumar, 2017). Namun, temuan makalah kami tidak konsisten sebelum studi empiris oleh (Stewart, 2016). Dapat disimpulkan bahwa EVA Perusahaan yang berkembang berdampak pada pasar mereka nilai tambah negatif. Di sisi lain, kita dapat mengatakan bahwa tidak ada hubungan antara MVA dan ukuran kinerja tradisional ROA. Namun pada ROE terdapat hubungan dengan Antara MVA dengan tingan laba investasi perusahaan.

Saran dari penulis adalah

1. Nilai tambah pasar (MVA) bukanlah factor utama dalam menentukan investasi, perlu juga ada faktor-faktor lain yang harus diperhatikan yang terdapat pada elemen laporan keuangan. 
2. Diharapkan variable penelitian perlu perluasan untuk berikutnya sehingga bisa memiliki cakupan yang lebih luas dan robust.

\section{REFERENSI}

Bernier, G., Mouelhi, C. (2015). Dynamic linkagesbetween MVA and internal performance measures: A panel cointegration analysis of the U.S. insurance industry. Assurances et Gestion Des Risques, 223-250.

Brynjolfsson, E., Hitt, L. . (2017). Beyond computation: Information technology, organizational transformation and business performance. Journal of Economic Perspective, 23-48.

Delaloye, J., Roger, T., Steiner-Tardivel, Q. G., Le Roy, D., Reymond, M. K., Akira, S., ... Calandra, T. (2009). Innate immune sensing of modified vaccinia virus Ankara (MVA) is mediated by TLR2-TLR6, MDA-5 and the NALP3 inflammasome. PLoS Pathogens. https://doi.org/10.1371/journal.ppat.1000480

Ewer, K., Rampling, T., Venkatraman, N., Bowyer, G., Wright, D., Lambe, T., ... Hill, A. V. S. (2016). A monovalent chimpanzee adenovirus ebola vaccine boosted with MVA. New England Journal of Medicine. https://doi.org/10.1056/NEJMoa1411627

Fathabadi, L., Fathi, D., Damiri, M. . (2016). Examining the relation of EVA (economic additional value) and ROE and ROA (return of assets) in cement and construction industries in TSE companies. International Journal of Academic Research in Accounting, Finance and Management Sciences, 205-209.

Ferguson, R., Rentzler, J., Yu, S. (2015). Does economic value added (EVA) improve stock performance profitability? The Journal of Applied Finance, 101-113.

Khan, S., Chouhan, V., Chandra, B., Goswami, S. (2016). Measurement of value creation Vis-ÀVis EVA: Analysis of select BSE companies. Pacific Business Review International, 114131.

Kramer, J.K., Pushner, G. (2017). An empirical analysis of economic value added as a proxy for market value added. Financial Practice and Education, 7(1), 41-49.

Lehn and Anil K. Makhija. (2016). EVA, ACCOUNTING PROFITS, AND CEO TURNOVER: AN EMPIRICAL
EXAMINATION. Journal of Applied Corporate Finance, 10(2), 81-89.

Liao, P., Hemmerlin, A., Bach, T. J., \& Chye, M. L. (2016). The potential of the mevalonate pathway for enhanced isoprenoid production. Biotechnology Advances. https://doi.org/10.1016/j.biotechadv.2016.03.0 05

Maditinos, D.I., Seviç, Z., Theriou, G. . (2017). The introduction of economic value added (EVA) in the Greek corporate sector. The South European Review of Business and Accounting, $182-201$.

Martias, A. (2017). Analisa Kinerja Keuangan Perusahaan Pendekatan Rasio Penentu di Bursa Efek Indonesia. Moneter, IV(2). Retrieved from http://ejournal.bsi.ac.id/ejurnal/index.php/mon eter/issue/view/204

Nakhaei, H., Hamid, N. I. . (2016). Analyzing the relationship between economic value added (EVA) and accounting variables with share market value in Tehran stock exchange (TSE). Journal of Accounting and Economics Teheran, 443-451.

Prasad, H., Shrimal, K. (2015). An empirical study on relationship between selected financial measures and market value added of infrastructural companies in India. Pacific Business Review International, 8(1), 95-97.

Reddy, N.R. V.R., Reddy, T. . (2015). Valuation through EVA and traditional measures an empirical study. International Journal of Trade, Economics and Finance, 2(1), 19-23.

Sharma, A.K., Kumar, S. (2017). Economic value added (EVA): Literature review and relevant issues. International Journal of Economics and Finance, 2(2), 200-220.

Sharma, A. K., \& Kumar, S. (2010). Economic Value Added (EVA) - Literature Review and Relevant Issues. International Journal of Economics and Finance. https://doi.org/10.5539/ijef.v2n2p200

Stewart, 3rd G.B. (2016). The EVA Management Guide. New York: Harper Business., 31-47.

Young, S.D.,O'Byrne, S. . (2017). EVA and Value Based Management: A Pratical Guide to Implementation New York. In Mc-Graw-Hill In (pp. 251-267). 